\title{
ANALISA FAKTOR MOTIVASI PERAWAT YAN BERHUBUNGAN DENGAN PELAKSANAAN ORIENTASI PASIEN BARU DI RUMAH SAKIT
}

\section{Analysis Of Nurse Motivation Factors Related To Implementing New Patient Orientation In Hospital}

\author{
Enggar Septhy Arsitha*, M. Ali Maulana**, Mita*** \\ *Mahasiswi Prodi Keperawatan Fakultas Kedokteran Universitas Tanjungpura, \\ Pontianak enggarsepthy29@gmail.com ** Dosen Keperawatan Fakultas Kedokteran \\ Universitas Tanjungpura, Pontianak ali.maulana85@gmail.com *** Dosen Keperawatan \\ Fakultas Kedokteran Universitas Tanjungpura, Pontianak mita@ners.untan.ac.id
}

\begin{abstract}
ABSTRAK
Latar Belakang: ciri khas individu saat masuk di lingkungan baru mengalami cemas, timbulnya harapan-harapan yang tidak realistis akibat kurang mendapatkan informasi yang jelas dan lengkap tentang lingkungan baru. Sehingga perlu ada orientasi pasien baru yang akan memberi dampak pada proses kesembuhan pasien dan citra rumah sakit. Terdapat beberapa faktor yang mempengaruhi pelaksanaan orientasi pasien baru salah satunya motivasi perawat.

Tujuan : menganalisis faktor motivasi perawat yang berhubungan dengan pelaksanaan orientasi pasien baru di RST TK.II Kartika Husada

Metode : penelitian kuantitatif, menggunakan desain penelitian survei analitik dengan pendekatan crosssectional study. Penelitian dilakukan di ruang rawat inap RST TK. II Kartika Husada Kubu Raya. Populasi pada penelitian in berjumlah 77 perawat. Pengambilan sampel menggunakan stratified random sampling sehingga didapatkan sampel berjumlah 43 perawat. Peneliti menggunakan lembar observasi untuk menilai pelaksanaan orientasi pasien baru dan kuesioner untuk menilai motivasi perawat. Data dianalisis secara univariat dengan distribusi frekuensi dan bivariat dengan Chi-Square.

Hasil : Nilai $p$ dari analisis hubungan prestasi, pengakuan, kemajuan, pekerjaan itu sendiri, tanggung jawab, hubungan interpersonal, supervisi, kebijakan rumah sakit, kondisi kerja dan gaji dengan pelaksanaan orientasi pasien baru terlihat lebih besar dari nilai signifikansi $p$.

Kesimpulan : tidak ada hubungan antara faktor motivasi perawat dengan pelaksanaan orientasi pasien baru dikarenakan observasi hanya dilakukan satu kali pada setiap responden dan kuesioner kurang dispesifikan kearah orientasi pasien baru.
\end{abstract}

Kata kunci : motivasi perawat, orientasi pasien baru 


\begin{abstract}
Background: common characteristics when entering a new environment is anxiety increasing, new environtment arise bizzare expectations because patient didn't get clear and complete information about the new environment. So there needs to be a new patient orientation that will have an impact on the patient's recovery process and to extend image of the hospital. The are a lot of factors that affect nurse ability to conduct new patient orientation such as motivation.
\end{abstract}

Aim: to analyze nurses motivational factors related to the implementation of new patient orientation in RST TK.II Kartika Husada.

Method: quantitative research, using analytical survey research design with cross sectional approach. The study was conducted in the inpatient room of RST TK.II Kartika Husada Kubu Raya. The population in this study were 77 nurses, using the stratified random sampling method to obtain a sample of 43 nurses. The researcher used a questionnaire to measure nurse motivation and observation sheets to measure the implementation of new patient orientation. Data were analyzed by univariate with frequency distribution and bivariate with Chi-Square.

Results: The value of $p$ from the analysis of the relationship of achievement, recognition, progress, work itself, responsibility, interpersonal relations, supervision, hospital policy, work conditions and salary with the implementation of new patient orientation $p$ values are $>0,05$.

Conclusion: all motivational factors, such as achievement, recognition, progress, work itself, responsibility, interpersonal relations, supervision, hospital policy, work conditions and salary have no correlation with the orientation of new patients by nurses.

Keywords: nurse, motivation, new patient orientation 


\section{PENDAHULUAN}

Ciri khas individu saat masuk di lingkungan baru yaitu mengalami cemas, timbulnya harapan-harapan yang tidak realistis akibat kurang mendapatkan informasi yang jelas dan lengkap tentang lingkungan baru 1,2 . Lingkungan baru pasien adalah instansi pelayanan rumah sakit. Jika pasien dan keluarga tidak mendapatkan informasi yang lengkap dan jelas tentang rumah sakit, akan terjadi peningkatan kecemasan yang menghambat proses terapi, pasien dan keluarga tidak patuh terhadap peraturan rumah sakit, pasien tidak kooperatif, timbulnya ketidakpuasan pasien terhadap pelayanan rumah sakit $3,4,5$. Pemberian informasi kepada pasien dan keluarga didapatkan saat pertama kali pasien masuk ke rumah sakit, yaitu pada proses orientasi pasien baru yang dilakukan perawat ${ }^{1}$.

Profesionalitas perawat dalam memberikan asuhan keperawatan menjadi tolak ukur keberhasilan pelayanan kesehatan di rumah sakit. Hal ini terkait dengan keberadaan perawat yang bertugas selama 24 jam melayani pasien, serta jumlah perawat yang mendominasi tenaga kesehatan di rumah sakit. Oleh karena itu, rumah sakit memerlukan perawat yang memiliki kinerja baik untuk menunjang pelayanan kesehatan sehingga dapat tercapai kepuasan pelanggan atau pasien ${ }^{2}$.

Peningkatan pelayanan keperawatan dapat diupayakan dengan meningkatkan kinerja perawat. Adapun aktivitas kerja perawat yaitu dari awal pasien masuk sampai pasien pulang. Sehingga orientasi pasien baru termasuk dalam kinerja perawat ${ }^{6}$.

Teori Keith Davis menyatakan bahwa faktor yang berhubungan dengan kinerja salah satunya adalah motivasi (motivation). Motivasi perawat mendorong perawat untuk melakukan pelayanan yang optimal ${ }^{7}$.

Penelitian sebelum yang dilakukan oleh Dermawanti bahwa terdapat hubungan motivasi kerja dengan kinja perawat ${ }^{8}$. Menurut Teori Frederick Herzberg ada dua faktor yang mendorong karyawan termotivasi dalam berkerja, yaitu faktor intrinsik (motivator factors) dan faktor ekstrinsik (hygiene factors) ${ }^{9}$

Studi pendahuluan dilakukan dengan mewawancarai 4 perawat pelaksana, 2 kepala ruangan dan 1 ketua tim. Terkait pelaksanaan orientasi pasien baru kepala ruangan menyatakan bahwa orientasi pasien baru tidak hanya dilakukan oleh kepala ruangan tetapi dapat juga dilakukan oleh perawat pelaksana maupun ketua tim. Empat perawat pelaksana mengatakan melakukan orientasi pasien baru. Satu ketua tim mengatakan melakukan orientasi pasien baru namun terkadang ada beberapa yang terlewatkan.

Terkait motivasi perawat dalam melaksanakan orientasi pasien baru dan tugas perawat lainnya, 4 perawat pelaksana mengatakan seringkali gaji yang diberikan tidak tepat waktu, perawat beranggapan gaji yang diberikan sudah sebanding dengan jasa. Tidak ada reward, mengerjakan tugas karena sudah menjadi tanggung jawab dan beberapa perawat mengatakan tidak menginginkan kenaikan jabatan karena akan menambah beban kerja. 
Kepala ruangan juga mengatakan mengerjakan tugas karena sudah menjadi tanggung jawab.

Peneliti juga mewawancarai pasien dan keluarga, didapatkan bahwa pasien dan keluarga mengetahui peraturan rumah sakit dari peraturan yang ditempelkan di dinding, dan informasi mengenai jam besuk sering diingatkan oleh perawat tetapi informasi lainnya tidak diketahui oleh pasien dan keluarga.

Berdasarkan masalah tersebut peneliti tertarik untuk melakukan penelitian mengenai analisa faktor motivasi perawat yang berhubungan dengan kinerja perawat dalam pelaksanaan orientasi pasien baru

\section{METODE}

Jenis penelitian ini adalah penelitian kuantitatif, dengan menggunakan desain penelitian survei analitik dengan pendekatan crosssectional study. Populasi pada penelitian ini adalah semua perawat yang bertugas di ruang rawat inap RST TK II Kartika Husada, Kubu Raya yang berjumlah 77 orang. Peneliti menggunakan teknik probability sampling dengan metode stratified random sampling dan menggunakan rumus baku yang diadopsi dari Lameshow sehingga didapatkan sampel 43 responden.

Variabel independen pada penelitian ini adalah hubungan antar pribadi, administrasi/ kebijakan rumah sakit, penyediaan/ pengawasan, gaji, kondisi kerja, prestasi, pengakuan, tanggung jawab, kemajuan/ promosi, pekerjaan itu sendiri. Variabel dependen pada penelitian ini adalah pelaksanaan orientasi pasien baru. Data pada penelitian ini dikumpulkan dengan melakukan observasi pelaksanaan orientasi pasien baru dengan lembar observasi dan kuesioner faktor motivasi perawat yang telah diuji validitas dan reabilitas. Data dianalisis secara univariat dengan distribusi frekuensi dan bivariat dengan Chi-Square.

\section{HASIL PENELITIAN}

\section{Analisa Univariat}

\begin{tabular}{ccc}
\hline $\begin{array}{c}\text { Motivasi } \\
\text { Perawat }\end{array}$ & $\mathbf{F}$ & $\%$ \\
\hline $\begin{array}{c}\text { Motivasi } \\
\text { Tinggi }\end{array}$ & 20 & 46,5 \\
\hline $\begin{array}{c}\text { Motivasi } \\
\text { Rendah }\end{array}$ & 23 & 53,5 \\
\hline
\end{tabular}

\begin{tabular}{ccc}
\hline $\begin{array}{c}\text { Pelaksanaan } \\
\text { Orientasi } \\
\text { Pasien Baru }\end{array}$ & F & \% \\
\hline Baik & 25 & 58,1 \\
\hline Kurang Baik & 18 & 41,9 \\
\hline
\end{tabular}




\begin{tabular}{|c|c|c|}
\hline Faktor-Faktor Motivasi Perawat & $\mathbf{f}$ & $\%$ \\
\hline \multicolumn{3}{|l|}{ Faktor Intrinsik } \\
\hline \multicolumn{3}{|l|}{ Prestasi (Achievement) } \\
\hline Motivasi Tinggi & 28 & 65,1 \\
\hline Motivasi Rendah & 15 & 34,9 \\
\hline \multicolumn{3}{|l|}{ Pengakuan (Recognition) } \\
\hline Motivasi Tinggi & 32 & 74,4 \\
\hline Motivasi Rendah & 11 & 25,6 \\
\hline \multicolumn{3}{|l|}{ Pekerjaan Itu Sendiri (Work In Self) } \\
\hline Motivasi Tinggi & 29 & 67,4 \\
\hline Motivasi Rendah & 14 & 32,6 \\
\hline \multicolumn{3}{|l|}{ Tanggung Jawab (Responsibility) } \\
\hline Motivasi Tinggi & 41 & 95,3 \\
\hline Motivasi Rendah & 2 & 4,7 \\
\hline \multicolumn{3}{|l|}{ Kemajuan/Promosi (Advancement) } \\
\hline Motivasi Tinggi & 24 & 55,8 \\
\hline Motivasi Rendah & 19 & 44,2 \\
\hline \multicolumn{3}{|l|}{ Faktor Ekstrinsik } \\
\hline \multicolumn{3}{|l|}{ Hubungan Antar Pribadi (Interpersonal Relation) } \\
\hline Motivasi Tinggi & 25 & 58,1 \\
\hline Motivasi Rendah & 18 & 41,9 \\
\hline \multicolumn{3}{|l|}{$\begin{array}{l}\text { Administrasi/Kebijakan Rumah Sakit } \\
\text { (Administration/Policy Hospital) }\end{array}$} \\
\hline Motivasi Tinggi & 24 & 55,8 \\
\hline Motivasi Rendah & 19 & 44,2 \\
\hline \multicolumn{3}{|l|}{ Penyediaan/Pengawasan (Supervision) } \\
\hline Motivasi Tinggi & 32 & 74,4 \\
\hline Motivasi Rendah & 11 & 25,6 \\
\hline \multicolumn{3}{|l|}{ Gaji (Salary) } \\
\hline Motivasi Tinggi & 24 & 55,8 \\
\hline Motivasi Rendah & 19 & 44,2 \\
\hline \multicolumn{3}{|l|}{ Kondisi Kerja (Working Condition) } \\
\hline Motivasi Tinggi & 28 & 65,1 \\
\hline Motivasi Rendah & 15 & 34,9 \\
\hline
\end{tabular}




\begin{tabular}{|c|c|c|c|c|c|}
\hline & & \multicolumn{2}{|c|}{$\begin{array}{c}\text { Pelaksanaan } \\
\text { Orientasi } \\
\text { Pasien Baru }\end{array}$} & \multirow[t]{2}{*}{ Total } & \multirow[t]{2}{*}{$\boldsymbol{P}$} \\
\hline & & Baik & $\begin{array}{c}\text { Kurang } \\
\text { Baik }\end{array}$ & & \\
\hline & & $\mathbf{F}$ & $\mathbf{f}$ & $\mathbf{F}$ & \multirow{3}{*}{0,407} \\
\hline \multirow{2}{*}{ Prestasi } & Motivasi Tinggi & 15 & 13 & 28 & \\
\hline & Motivasi Rendah & 10 & 5 & 15 & \\
\hline \multirow{2}{*}{ Pengakuan } & Motivasi Tinggi & 21 & 11 & 32 & \multirow{2}{*}{0,156} \\
\hline & Motivasi Rendah & 4 & 7 & 11 & \\
\hline \multirow{2}{*}{ Pekerjaan Itu Sendiri } & Motivasi Tinggi & 16 & 13 & 29 & \multirow{2}{*}{0,570} \\
\hline & Motivasi Rendah & 9 & 5 & 14 & \\
\hline \multirow{2}{*}{ Tanggung Jawab } & Motivasi Tinggi & 25 & 16 & 41 & \multirow{2}{*}{0,169} \\
\hline & Motivasi Rendah & 0 & 2 & 2 & \\
\hline \multirow{2}{*}{ Kemajuan } & Motivasi Tinggi & 15 & 9 & 24 & \multirow{2}{*}{0,515} \\
\hline & Motivasi Rendah & 10 & 9 & 19 & \\
\hline \multirow{2}{*}{ Hubungan Antar Pribadi } & Motivasi Tinggi & 16 & 9 & 25 & \multirow{2}{*}{0,359} \\
\hline & Motivasi Rendah & 9 & 9 & 18 & \\
\hline \multirow{2}{*}{ Kebijakan Rumah Sakit } & Motivasi Tinggi & 17 & 7 & 24 & \multirow{2}{*}{0,58} \\
\hline & Motivasi Rendah & 8 & 11 & 19 & \\
\hline \multirow{2}{*}{ Pe gawasan } & Motivasi Tinggi & 19 & 13 & 31 & \multirow{2}{*}{1,00} \\
\hline & Motivasi Rendah & 6 & 5 & 11 & \\
\hline \multirow{2}{*}{ Gaji } & Motivasi Tinggi & 13 & 11 & 24 & \multirow{2}{*}{0,553} \\
\hline & Motivasi Rendah & 12 & 7 & 19 & \\
\hline \multirow{2}{*}{ Kondisi Kerja } & Motivasi Tinggi & 16 & 12 & 28 & \multirow{2}{*}{0,856} \\
\hline & Motivasi Rendah & 9 & 6 & 15 & \\
\hline
\end{tabular}

Prestasi, pengakuan, kemajuan, pekerjaan itu sendiri, tanggung jawab, hubungan interpersonal, supervisi, kebijakan rumah sakit, kondisi kerja dan gaji tidak memiliki hubungan dengan pelaksanaan orientasi pasien baru. 


\section{PEMBAHASAN}

\section{Pelaksanaan Orientasi Pasien Baru}

Pelaksanaan orientasi pasien baru secara keseluruhan dilakukan dengan baik oleh perawat. Namun dari setiap subtansi, perawat masih belum optimal dalam pelaksanaan orientasi pasien baru.

Orientasi pasien baru merupakan bagian dari penerimaan pasien baru ${ }^{2}$. Sehingga orientasi pasien baru dapat dikatakan efektif dan optimal apabila dilakukan pada saat proses penerimaan pasien baru di ruang rawat inap. Pelaksanaan orientasi pasien baru di ruang rawat inap tidak selalu dilakukan bersamaan dengan penerimaan pasien baru. Hal ini dikarenakan jumlah pasien yang lebih banyak dari perawat yang jaga setiap shift sehingga perawat tergesagesa dalam melakukan orientasi pasien baru.

\section{Faktor Motivasi Perawat}

Tanggung jawab merupakan faktor motivasi tertinggi yang dimiliki oleh perawat. Hal ini sesuai dengan penelitian Pordaningsih yang menyatakan perawat dengan rasa tanggung jawab tinggi terhadap pekerjaan dapat meningkatkan motivasi kerja dari pada perawat dengan tanggung jawab rendah ${ }^{10}$. Sehingga rumah sakit dapat terus mempertahankan motivasi perawat yang tinggi terhadap tanggung jawab dengan terus memberikan tanggung jawab berupa kepercayaan sesuai potensi yang dimiliki perawat.

Kebijakan dan administrasi perusahaan (rumah sakit) adalah tingkat kesesuaian yang dirasakan pegawai (perawat) terhadap semua kebijakan dan peraturan yang berlaku dalam perusahaan ${ }^{11}$. Penelitian yang dilakukan oleh Cahyani, Wahyuni, \& Karuniawan menyatakan kebijakan dan administrasi yang kurang baik akan mempengaruhi perasaan dan semangat kerja pegawai (perawat) ${ }^{12}$.

Kebijakan rumah sakit merupakan faktor motivasi dengan skor terendah, sehingga rumah sakit harus berupaya untuk meningkatkan motivasi perawat melalui kebijakan rumah sakit. Menurut penelitian Cumber \& Elive tentang The Identification of Motivational Factors That Influences Nurses Output in Hospitals in the Fako Division, Cameroon menunjukkan sebagian besar perawat lebih suka kebijakan rumah sakit yang ketat $(58,9 \%)$ karena mendorong mereka untuk bekerja lebih baik dibandingkan bagi mereka yang memilih kebijakan rumah sakit yang longgar ${ }^{13}$. Karyawan juga mempertimbangkan kebijakan perusahaan seperti kontes untuk pekerja terbaik pada akhir tahun, sertifikat untuk karyawan berprestasi dan publikasi kinerja yang baik dalam perusahaan sebagai aspek yang memotivasi mereka untuk kinerja yang lebih baik ${ }^{14}$.

Gaji/upah/imbalan adalah balas jasa dalam bentuk uang yang diterima pegawai (perawat) sebagai konsekuensi dari kedudukannya sebagai pegawai yang memberikan sumbangan dalam mencapai tujuan organisasi (rumah sakit). Pegawai (perawat) yang mendapatkan gaji sesuai dengan usaha kerja yang dilakukannya atau sesuai dengan 
harapannya akan membuat pegawai bekerja dengan lebih baik dan sungguh-sungguh ${ }^{15}$.

Substansi gaji pada penelitian ini merupakan faktor dengan skor terendah. Rumah sakit dapat mengoptimalkan motivasi dengan pemberian gaji tepat waktu memberikan tunjangan atau kenaikan gaji secara berkala sesuai lama kerja masing-masing individu, serta memberikan bonus bagi perawat yang berprestasi sehingga akan meningkatkan kinerja perawat khususnya dalam pelaksanaan orientasi pasien baru.

\section{Faktor Motivasi Perawat yang Berhubungan dengan Pelaksanaan Orientasi Pasien Baru}

Faktor motivasi perawat tidak memiliki hubungan dengan pelaksanaan orientasi pasien baru di RST TK.II Kartika Husada. Peneliti menilai ada beberapa alasan yang menyebabkan hal ini terjadi.

Alasan pertama yaitu pernyataan pada kuesioner persubstansi motivasi perawat belum maksimal dispesifikan kearah pelaksanaan orientasi pasien baru. Pernyataan pada faktor prestasi, kemajuan, pekerjaan itu sendiri, supervisi, kondisi kerja dan gaji belum spesifik diarahkan pada pelaksanaan orientasi pasien baru dan masih mengarah pada tugas perawat secara umum. Karena itulah, pada hasil analisa chi square terlihat ketidak kontrasan yaitu pelaksanaan orientasi pasien baru dilakukan dengan baik oleh perawat dengan motivasi tinggi maupun perawat dengan motivasi rendah.

Sedangkan pernyataan pada faktor hubungan antar pribadi, dari 6 pernyataan hanya 1 pernyataan yang diarahkan pada pelaksanaan orientasi pasien baru. Sehingga responden yang memiliki motivasi tinggi melakukan orientasi pasien baru dengan baik, dan pada responden dengan motivasi rendah seimbang dalam pelaksanaa orientasi pasien baru dengan baik dan kurang baik.

Berbeda dengan faktor pengakuan, tanggung jawab dan kebijakan rumah sakit sudah diarahkan pada pelaksanaan orientasi pasien baru. Sehingga hasil analisa chi square terlihat kontras, yaitu perawat yang memiliki motivasi tinggi melakukan orientasi pasien baru dengan baik dan perawat yang memiliki motivasi rendah kurang baik dalam pekasanaaan orientasi pasien baru.

Alasan kedua yaitu observasi pelaksanaan orientasi pasien baru hanya dilakukan satu kali pada setiap responden. Sehingga peneliti tidak dapat mengukur ketaatan atau kekonsistenan responden dalam melakukan orientasi pasien baru. Berdasarkan Teori Efek Hawthorne mengatakan bahwa respon individu ketika tahu bahwa sedang diawasi adalah berusaha untuk meningkatkan perilaku mereka. Sehingga peneliti menilai bias terjadi sangat besar karena alasan ini.

Alasan ketiga yang menyebabkan tidak adanya hubungan yaitu alat ukur motivasi perawat menggunanan kuesioner. Sehingga responden bebas memilih jawaban berdasarkan keinginannya dan peneliti tidak dapat mengukur tingkat kejujuran responden.

$\begin{array}{ccr}\text { Alasan } & \text { keempat } & \text { yang } \\ \text { menyebabkan } & \text { tidak } & \text { adanya } \\ \text { hubungan yaitu } & \text { jumlah } & \text { responden }\end{array}$


dalam penelitian terbatas dengan jumlah 43 orang. Sehingga hasilnya belum bisa digeneralisasikan pada penelitian jumlah responden yang lebih banyak. Penelitian sebelumnya yang dilakukan oleh Haerani, Ake \& As'ad yang menunjukan adanya hubungan antara motivasi ekstrinsik dengan kinerja perawat dalam pelaksanaan asuhan keperawatan menggunakan sempel sebanyak 90 orang $^{16}$. Demikian juga pada penelitian Pramana yang menyatakan ada hubungan antara motivasi intrinsik dengan kinerja perawat menggunakan sempel sebanyak 97 orang $^{17}$.

\section{KESIMPULAN}

Pelaksanaan orientasi pasien baru di ruang rawat inap RST TK.II Kartika Husada belum optimal dan efektif. Motivasi perawat di ruang rawat inap RST TK.II Kartika Husada masuk dalam kategori rendah. Motivasi tertinggi yang dimiliki perawat adalah tanggung jawab. Tidak ada hubungan antara faktor motivasi perawat dengan pelaksanaan orientasi pasien baru di ruang rawat inap RST TK.II Kartika Husada. Penelitian selanjutnya dapat menggunakan metode kombinasi agar mendapatkan data yang lengkap dan menyeluruh dengan mengobservasi seluruh responden yang kemudian diberikan kuesioner.

\section{DAFTAR PUSTAKA}

1. Ismainat, H. Administrasi Kesehatan Masyarakat. Jakarta: Gramedia, 2015.
2. Potter, P.A. dan A.G. Perry. Buku ajar fundamental keperawatan: konsep, proses, dan praktik (Edisi 4). Jakarta: EGC, 2010.

3. Firdausi, Nugrahaeni. Tingkat Kecemasan Pada Pasien Yang Hospitalisasi. Jurnal AKP 2015:10-14.

4. Sari, Elia Intan;Rofli, Muhamad. Gambaran Perawat Dalam MelakukanOrientasi Pasien Baru di Instalasi Rwat Inap RSUD HJ. Anna Lasmanah Banjarnegara. E-Journal Undip 2017.

5. Pratiwi, Widya Dwi.,Sari, Yeni Kartika. Pengaruh orientasi pasien baru terhadap tingkat kepuasan pasien. Jurnal ners dan kebidanan, 2014: Vol 1(1)

6. Swansburg, R. Pengantar kepemimpinan dan manajemen keperawatan. Alih Bahasa: Sunaryati Samba Editor: Monica Ester. Jakarta: EGC, 2000.

7. Satrianegara, M., \& Sitti, S. Buku Ajar Organisasi dan Manajemen Pelayanan Kesehatan serta Kebidanan. Jakarta: Salemba Medika, 2009.

8. Darmawanti, R. Hubungan Motivasi Kerja Dengan Kinerja Perawat Rawat Inap Di Rumah Sakit Sultan Syarif Mohamad Alkadrie Pontianak Tahun 2015. Jurnal Proners 2015: 1.

9. Bagia, I.W. Perilaku organisasi. Yogyakarta: Graha Ilmu, 2015.

10. Pordaningsih, Renny. Hubungan Antara Tanggung Jawab, Imbalan Dan Supervisi Dengan Motivasi Kerja Perawat Di Ruang Rawat Inap Rsud Sungai Gelam Muaro Jambi. Jurnal Akper Garuda Putih 2015: Vol.1 (2) 
11. Siagian, Sondang P. Kiat Meningkatkan Produktivitas Kerja. Jakarta: PT. Rineka Cipta, 2012.

12. Cahyani, Intan Dwi., Wahyuni, Ida.,Kurniawan, Bina. Faktorfaktor yang berhubungan dengan motivasi kerja pada perawat rumah sakit jiwa. Jurnal kesehatan masyarakat 2016 : Vol 4(2).

13. Camber, Samuel Nambile. Elive, Stanly Mbua. The Identification of Motivational Factors That Influences Nerses Output in the Fako Division, Cameroon. Jounal of Family Medicine and Health Care 2016: Vol 2 (4) 7480

14. Buchory, H.A. dan Saladin, Djaslim, Pengantar Bisnis, cetakan 2, Bandung: Linda karya, 2009.

15. Hariandja ,Marihot Tua Effendi. Manajemen Sumber Daya Manusia, Edisi Revisi, Cetakan Kedua, Jakarta: PT. Grasindo, 2010.

16. Haerani. Ake, Julianus. \& As'ad, Suryani. Hubungan Motivasi Ekstrinsik dengan Kinerja Perawat Pelaksana Asuhan Keperawatan. JST Kesehatan 2015: Vol 5 (1) 90-96

17. Permana, Indra Surya. Sedjati, Retina Sri. \& Kusniasih, Nining. Pengaruh Faktor Motivasi Intrinsik dan Ekstrinsik Terhadap Kinerja Perawat di RSUD 45 Kabupaten Kuningan. Jurnal Ekonomi 2017: Vol 6 (1) 130148. 